Review Article

\title{
Xanthine Oxidase-Induced Inflammatory Responses in Respiratory Epithelial Cells: A Review in Immunopathology of COVID-19
}

\author{
Irandi Putra Pratomo, ${ }^{1,2,3}$ Dimas R. Noor, ${ }^{4}$ Kusmardi Kusmardi, ${ }^{4,5,6}$ \\ Andriansjah Rukmana, ${ }^{7}$ Rafika I. Paramita, ${ }^{3,8,9}$ Linda Erlina, ${ }^{3,8,9}$ Fadilah Fadilah, ${ }^{3,8,9}$ \\ Anggi Gayatri, ${ }^{10}$ Magna Fitriani, ${ }^{11}$ Tommy T. H. Purnomo, ${ }^{11}$ Anna Ariane, ${ }^{12}$ \\ Rudi Heryanto, ${ }^{13,14}$ and Aryo Tedjo ${ }_{(D)}^{6,8,9}$
}

${ }^{1}$ Department of Pulmonology and Respiratory Medicine, Faculty of Medicine, Universitas Indonesia, Jakarta, Indonesia

${ }^{2}$ COVID-19 Task Force-Pulmonology and Respiratory Medicine Unit, Universitas Indonesia University Hospital, Universitas Indonesia, Depok, Indonesia

${ }^{3}$ Bioinformatics Core Facilities, Indonesian Medical Education and Research Institute, Faculty of Medicine, Universitas Indonesia, Jakarta, Indonesia

${ }^{4}$ Human Cancer Research Center, Indonesian Medical Education and Research Institute, Faculty of Medicine, Universitas Indonesia, Jakarta, Indonesia

${ }^{5}$ Department of Pathology Anatomy, Faculty of Medicine, Universitas Indonesia, Jakarta, Indonesia

${ }^{6}$ Drug Development Research Cluster, Indonesian Medical Education and Research Institute, Faculty of Medicine, Universitas Indonesia, Jakarta, Indonesia

${ }^{7}$ Department of Microbiology, Faculty of Medicine, Universitas Indonesia, Jakarta, Indonesia

${ }^{8}$ Department of Medical Chemistry, Faculty of Medicine, Universitas Indonesia, Jakarta, Indonesia

${ }^{9}$ Master's Programme in Biomedical Sciences, Faculty of Medicine, Universitas Indonesia, DKI Jakarta, Depok, Indonesia

${ }^{10}$ Department of Pharmacology, Faculty of Medicine, Universitas Indonesia, Jakarta, Indonesia

${ }^{11}$ Universitas Indonesia University Hospital, Universitas Indonesia, Depok, Indonesia

${ }^{12}$ Division of Rheumatology, Department of Internal Medicine, Faculty of Medicine,

Universitas Indonesia-Dr. Cipto Mangunkusumo Hospital, Jakarta, Indonesia

${ }^{13}$ Department of Chemistry, Faculty of Mathematics and Natural Sciences, IPB University, Bogor, Indonesia

${ }^{14}$ Tropical Biopharmaca Research Center, IPB University, Bogor, Indonesia

Correspondence should be addressed to Aryo Tedjo; 1aryo.tedjo@gmail.com

Received 17 April 2021; Revised 9 July 2021; Accepted 19 July 2021; Published 6 August 2021

Academic Editor: Han J. Moshage

Copyright (C) 2021 Irandi Putra Pratomo et al. This is an open access article distributed under the Creative Commons Attribution License, which permits unrestricted use, distribution, and reproduction in any medium, provided the original work is properly cited.

Xanthine oxidase $(\mathrm{XO})$ is an enzyme that catalyzes the production of uric acid and superoxide radicals from purine bases: hypoxanthine and xanthine and is also expressed in respiratory epithelial cells. Uric acid, which is also considered a danger associated molecule pattern (DAMP), could trigger a series of inflammatory responses by activating the inflammasome complex path and NF- $\kappa \mathrm{B}$ within the endothelial cells and by inducing proinflammatory cytokine release. Concurrently, XO also converts the superoxide radicals into hydroxyl radicals that further induce inflammatory responses. These conditions will ultimately sum up a hyperinflammation condition commonly dubbed as cytokine storm syndrome (CSS). The expression of proinflammatory cytokines and neutrophil chemokines may be reduced by XO inhibitor, as observed in human respiratory syncytial virus (HRSV)infected A549 cells. Our review emphasizes that XO may have an essential role as an anti-inflammation therapy for respiratory viral infection, including coronavirus disease 2019 (COVID-19). 


\section{Introduction}

Uric acid (UA) is a Danger Associated Molecule Pattern (DAMP) released in stress conditions and is associated with nonspecific inflammation response [1] or neutrophils recruitment to the inflammation sites [2]. Uric acid can activate NALP3 inflammasomes, causing neutrophilic inflammation and interleukin (IL) $-1 \beta$ proinflammatory cytokine release $[3,4]$. In primates, uric acid is catalyzed by xanthine dehydrogenase $(\mathrm{XDH})$ and xanthine oxidase (XO) [5]. Xanthine dehydrogenase, which is expressed in various tissues such as the liver and intestine, is also associated with the increase of proinflammatory cytokines, such as IL- $1 \beta$, tumor necrosis factor (TNF)- $\alpha$, and interferon (IFN) $-\gamma[6,7]$.

Xanthine oxidase oxidizes xanthine with the aid of molybdenum cofactor by transferring the electron via two $\mathrm{Fe}-\mathrm{S}$ clusters to the flavin adenine dinucleotide (FAD) coenzyme part to reduce oxygen and reduce nicotinamide adenine dinucleotide (NAD) ${ }^{+}$into $\mathrm{NADH}$ [6]. The oxidative reaction of molybdenum is highly dependent on $\mathrm{pH}$ and oxygen pressure. In physiological conditions, hypoxanthine and xanthine concentrations in the cell ranged around $1-3 \mu \mathrm{M}$, while in hypoxic conditions, the concentrations of hypoxanthine and xanthine increase to about $50-100 \mu \mathrm{M}$ and cause $\mathrm{pH}$ reduction to 7 [6]. In that condition, this enzyme undergoes a posttranslation modification in the $535^{\text {th }}$ and $992^{\text {nd }}$ cysteine residues or proteolysis, resulting in $\mathrm{XDH}$ conversion into $\mathrm{XO}$ [8].

The electron-transfer affinity (electron flux) of $\mathrm{NAD}^{+}$ in the FAD site decreases and the affinity to the oxygen increases during the hypoxic condition. This will cause univalent and divalent electron-transfer generating superoxide or hydrogen peroxide $[6,9]$. Therefore, XO is considered one of the peroxide sources in the cells and associated with hypoxic injury [10]. The superoxide generated by the xanthine oxidase could react with nitric oxide (NO) that subsequently will produce peroxynitrite, causing a decrease in NO bioavailability, which then results in reduction in endothelial dysfunction [6]. This alteration is also triggered by the interaction between the positively charged $\mathrm{XO}$ and the negatively charged glycosaminoglycan (GAG) on the endothelial surface $[11,12]$. Accumulation of XO may also lead to the production of reactive oxygen species (ROS) as superoxide radicals, which could increase the production of hydrogen peroxide triggering endothelial dysfunction [13]. Various reports stated that $\mathrm{XO}$ activities can lead to harmful systemic conditions, such as heart attack, chronic obstructive pulmonary disease, pulmonary hypertension, and diabetes mellitus (DM) type 1 and type 2, which are also associated with endothelial dysfunction $[6,14,15]$.

The respiratory virus is known to induce the ROSproducing enzymes, including nicotinamide adenine dinucleotide phosphate oxidase (Nox) and XO, as it was observed in influenza virus (IV), human respiratory syncytial virus (HRSV), and human rhinovirus (HRV)-infected respiratory epithelial cells [16]. For example, in bronchial epithelial cells A549 (respiratory epithelial cells) infected by $\mathrm{HRSV}$, it is seen that the $\mathrm{XO}$ catalysis product (uric acid) and $\mathrm{XO}$ inhibitor (Allopurinol) conversely affect (antagonize) the inflammation process, in this case, the release of proinflammation cytokine and chemokine as neutrophils chemoattractant [2]. The role of XO, the catalysis products (uric acid and superoxide radicals), and XO inhibitors in affecting the inflammation process in respiratory virus infection will be described below.

\section{Inflammatory Mechanism of Uric Acid due to RNA Virus Infection}

Uric acid is expected to trigger IL-1 release through the complex activation pathway of inflammasome and caspase- 1 via $\mathrm{P} 2 \mathrm{X} 7$ receptor expressed in the surface of the respiratory tract cells, including its lymphocyte [17] and macrophage cells [18]. In incubated human umbilical vein endothelial cells (HUVECs), uric acid is also found to increase the expression of the NLRP3 inflammasome and IL-1 $\beta$, which by the addition of a high concentration of $\mathrm{K}^{+}$and ROS inhibitor results in the reduction of NLRP3 inflammasome expression [19]. This shows that uric acid activates the NLRP3 inflammasome through ROS intermediary or by regulating the $\mathrm{K}^{+}$efflux [19], which is assumed through the interaction of uric acid and P2X7 receptors as its ligands $[17,18]$. This, like a study by Neumann et al., shows that the interaction between $\mathrm{P} 2 \mathrm{X} 7$ receptors and ATPs besides triggering the inflammasome activity, also causing $\mathrm{K}^{+}$efflux [20]. Moreover, uric acid can also trigger inflammation by activating nuclear factor kappa $\mathrm{B}(\mathrm{NF}-\kappa \mathrm{B})$ through the signaling pathway of HMGB1/RAGE [21] and by increasing the expression of toll-like receptors (TLR)-4, NLRP3, and ICAM-1 [22]. Inflammatory mechanisms of uric acid are summarized in Table 1.

A study by da Costa et al. showed that NLRP3 inflammasome activation during RNA virus infection is also caused by the host cell structural damage (cytopathogenic) via the intermediary/regulation of $\mathrm{K}^{+}$efflux [24]. A respiratory infection caused by RSV, a negative-single stranded RNA virus, also strongly induces the expression of HMGB1, both in vitro and in vivo [25]. On the other hand, Pacheco et al. strongly suspected that there is an involvement of P2X7 receptors in the pathogenesis of severe acute respiratory syndrome corona virus-2 (SARS-CoV-2) inflammation [26]. A supportive clinical observation, reported by Huang et al., demonstrated an increase in the number of blood neutrophils in COVID-19 patients when compared to healthy subjects and in intensive care unit (ICU) patients when compared to non-ICU patients [27]. Neutrophils increase the expression of P2X7 receptors and can release IL- $1 \beta$ through the activation of NLRP3 inflammasome intermediated by ATP [26] or triggered by the interaction between P2X7 receptors and ATPs [20]. Extracellular ATP is known to be the key mediator in inflammation in lung fibrosis [28]. The existing clinical 
TABLE 1: Inflammatory mechanism of uric acid.

\begin{tabular}{|c|c|c|c|}
\hline Secretion/expression & Cell & Mechanism & Reference \\
\hline IL-1 & Lymphocyte & $\begin{array}{c}\text { Activation of inflammasome and caspase-1 complex } \\
\text { via } \mathrm{P} 2 \mathrm{X} 7 \text { receptor }\end{array}$ & [17] \\
\hline IL- $1 \beta$ & Macrophage & $\begin{array}{l}\text { Activate the inflammasome via } \mathrm{P} 2 \mathrm{X} 7 \text { signaling, } \\
\text { and treatment with a } \mathrm{P} 2 \mathrm{X} 7 \text { inhibitor reduces } \mathrm{IL}-1 \beta \text { release }\end{array}$ & {$[18]$} \\
\hline IL- $1 \beta$ & $\begin{array}{l}\text { Human umbilical vein } \\
\text { endothelial cells (HUVECs) }\end{array}$ & $\begin{array}{c}\text { Regulate the activation of NLRP3 inflammasome by } \\
\text { activation of ROS and } \mathrm{K}+\text { efflux }\end{array}$ & [19] \\
\hline IL- 6 and TNF- $\alpha$ & $\begin{array}{l}\text { Human umbilical vein } \\
\text { endothelial cells (HUVECs) }\end{array}$ & $\begin{array}{l}\text { High concentrations of UA significantly increased } \\
\text { mRNA expression and extracellular } \\
\text { release of HMGB1 from human umbilical vein } \\
\text { endothelial cells (HUVECs) [23]. } \\
\text { Extracellular HMGB1 binding to RAGE activates } \\
\text { NF- } \kappa \text { B, which leads to proinflammation. }\end{array}$ & [21] \\
\hline IL- $1 \beta$ & Renal tubular epithelial cells (HK-2) & $\begin{array}{l}\text { UA, like Lipopolysaccharides (LPS), significantly enhanced } \\
\text { the expression of TLR4, NLRP3, IL- } 1 \beta \text {, and ICAM- } 1\end{array}$ & {$[22]$} \\
\hline
\end{tabular}

data, radiography, and autopsies show that patients who suffer from coronavirus infection are at risk for lung fibrosis, and evidence shows that lung fibrosis also occurs in COVID-19 [29]. Based on the above explanation, it can be concluded that there is an inflammatory mechanism between RNA virus infection and uric acid.

\section{Inflammatory Mechanism of XO and Its Catalytic Products due to Respiratory Virus Infection}

Inflammation of host cells, both directly by the virus (through the cytopathogenic activity) and indirectly by the $\mathrm{XO}$ activity products, which is uric acid, contributes to the activity of the IL- $1 \beta$ cytokine. Research by Fonseca et al. also proved this, where the addition of XO inhibitor (Allopurinol) to the bone marrow-derived macrophages (BMDMs) infected by HRSV showed a decrease in expression and IL$1 \beta$ level compared to without any addition of $\mathrm{XO}$ inhibitor [2]. There was an increase in IL- $1 \beta$ expression compared to without the addition of uric acid. Uric acid and XO activity were suspected of having important roles during HRSV infection, especially in the initial phase of HRSV infection. It is indicated in the increase of uric acid level in bronchoalveolar lavage fluid of infant mouse infected by HRSV two days postinfection. This increase in uric acid in BALF was also accompanied by the increase in the expression of $\mathrm{XO}$ in lung cells.

Respiratory cells inflammation due to respiratory virus infection could more massively occur. Alveoli epithelium is mostly (90\%) AT1 cells. The infection of rat coronavirus $(\mathrm{RCoV})$ to the AT1 cells will induce more expression of IL$1 \alpha$ and IL- $1 \beta$, which will further send more signals through the IL-1 receptor (IL-1R) of the cells not infected in order to induce more CXC chemokine release. The many numbers of CXC will then trigger more neutrophils to come to the site of the infected cells [30]. The illustration of neutrophils recruitments in RCoV infection is shown in Figure 1.

Neutrophils (and monocyte) recruitment, passing from the endothelium to the infected cells, is significantly contributed to the increase in production of superoxide anion by the Nox2 during infection by the virus [16]. The superoxide anion radicals generated by the activity of the neutrophils during the process of phagocytosis, in the presence of superoxide dismutase (SOD) enzyme, will be converted into hydrogen peroxide $\left(\mathrm{H}_{2} \mathrm{O}_{2}\right)$ compound. Yasui et al. demonstrated that exogenous SOD can induce neutrophils apoptosis, which means $\mathrm{H}_{2} \mathrm{O}_{2}$ is a mediator inhibiting the inflammation caused by the neutrophils [23]. Although the formation of $\mathrm{H}_{2} \mathrm{O}_{2}$ can inhibit the inflammation through the neutrophil's apoptosis, the next reaction of the $\mathrm{H}_{2} \mathrm{O}_{2}$ also induces an inflammation reaction. By way of Fenton reaction, $\mathrm{H}_{2} \mathrm{O}_{2}$ will react with $\mathrm{Fe}^{3+}$ to produce $\cdot \mathrm{OH}$ radicals. The . $\mathrm{OH}$ radical is known to have a role in inducing IL-6 cytokine [31], which is a proinflammation agent that appears as a cytokine storm syndrome (CSS) marker, as found in patients with acute respiratory distress syndrome (ARDS) [32].

IL- 6 production is also intermediated by uric acid. Cai et al. showed that, similar to the epithelial cells, in endothelial cells, uric acid stimulates the signaling pathway of HMGB1/RAGE, which activates NF- $\kappa$ B. The activation of $\mathrm{NF}-\kappa \mathrm{B}$ then induces the production and release of IL- 6 and TNF- $\alpha$ and triggers endothelial dysfunction [21].

Aside from Nox, superoxide anion production is also known to occur due to XO activity in the epithelial and endothelial cells. Fonseca et al. showed that the provision of $\mathrm{XO}$ inhibitor (Allopurinol) to HRSV-infected A549 cells indicates a reduced expression of XO, IL-33, and CCL2, compared to the cells without any allopurinol provision [2]. The opposite occurs when HRSV-infected A549 cells are added with uric acid, where there is an increased expression of XO, IL-33, and CCL2, compared to those not added with uric acid. Currently, IL-33 is described as a member of the IL-1 family expressed in large amounts in the epithelial and endothelial cells [33]. It is also described previously that during the infection of $\mathrm{RCoV}$, the interaction between IL-1 and its receptor in epithelial cells of alveolus will induce CXC chemokine secretion [34]. Both CCL2 [34] and CXC [30] are chemokines with roles as neutrophils chemoattractants. A similar condition was also found in rhinovirus- (RV)-infected A549 cells; oxypurinol acts to reduce the production of superoxide radicals, IL- 8 and CXCL1 


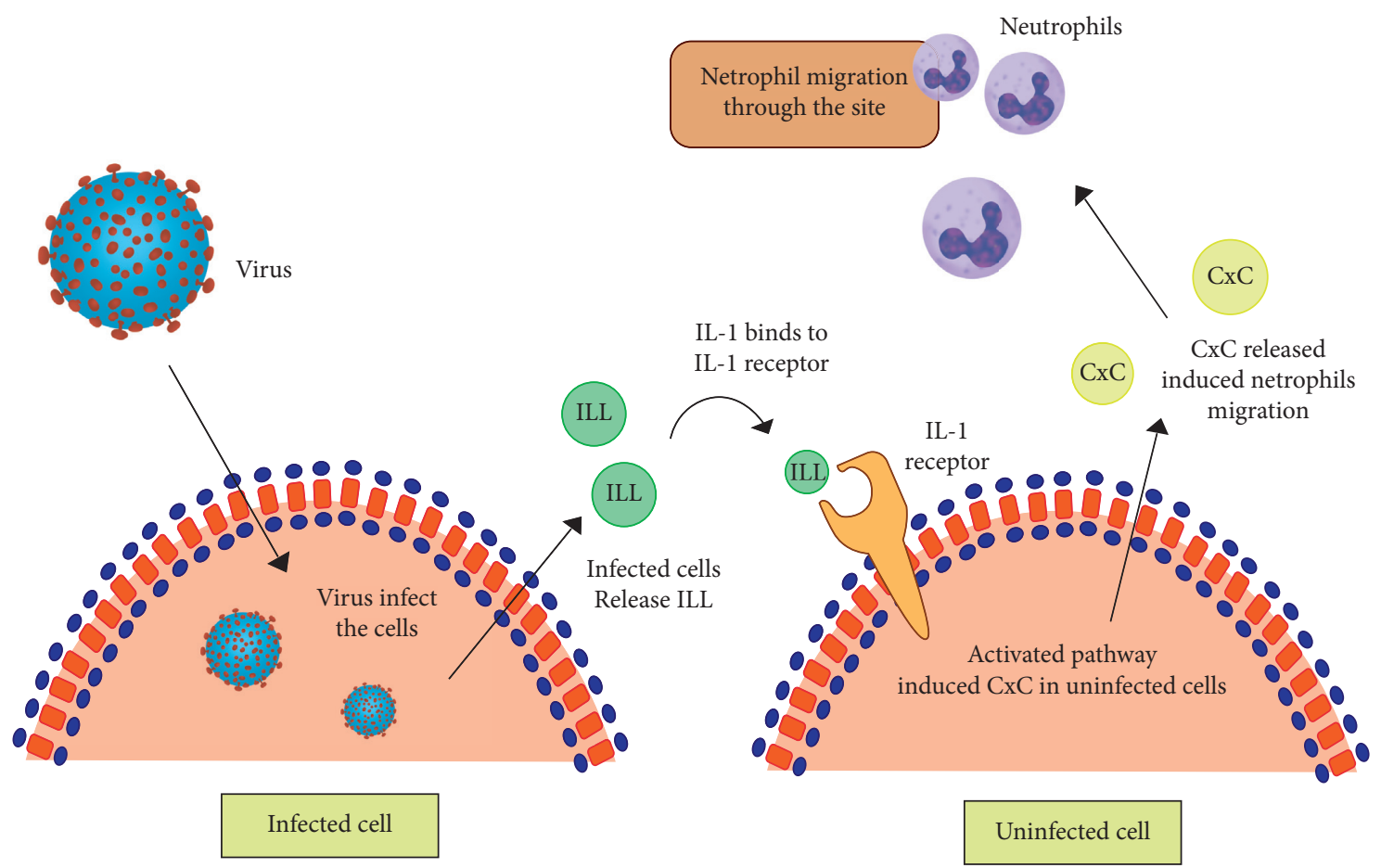

FIgURE 1: Neutrophils recruitment during RCoV infection. RCoV infects AT1 cells, induces secretion of IL-1, induces CXC in uninfected cells, and triggers neutrophils recruitment (adaptation from Miura et al. [30]).

[35]. It can be concluded that XO inhibitors act to reduce neutrophils' recruitment to the infected cells, which eventually can also inhibit the secretion of proinflammation cytokine.

According to Chen et al., serum uric acid level $>423 \mathrm{~mol} / \mathrm{L}$ was associated with an increased risk of composite outcome and mechanical ventilation, whereas a level of $278 \mathrm{~mol} / \mathrm{L}$ was associated with an increased risk of the composite outcome, ICU care, and mechanical ventilation [36]. The condition of hypouricemia can be associated with proximal tubular damage due to viral infection and gout [37]. Damage to the proximal tubule is known from an increase in urinary uric acid levels as happened in SARS patients and COVID-19, which indicates impaired uric acid reabsorption [38]. Thus, it can be hypothesized that during SARS-COV-2 infection, there is an increase in $\mathrm{XO}$ activity. It is just that when the amount of uric acid and/ or the amount of virus in the circulation increases, hypouricemia can occur as described above. Such a process is described in Figure 2.

\section{Systemic Impact of Inflammatory Properties of XO due to Respiratory Virus Infection}

In the review above, it has been described that during respiratory virus infection, $\mathrm{XO}$ and its reaction products, i.e., superoxide anions and uric acid, have important roles in the formation of proinflammation cytokine in macrophage cells [2], epithelial cells $[2,30]$, and endothelial cells $[19,21]$.
Proinflammatory cytokine formed during the respiratory virus infection are IL- 1 , TNF- $\alpha$, and IL- 6 . As is the case with COVID-19, there is an increase in IL- $1 \beta$, IL-6, and C-reactive protein (CRP) [39]. Susilo et al. reported that proinflammation cytokine, i.e., TNF- $\alpha$, IL- 1 , and IL-6, also IL-8, infection markers such as procalcitonin, ferritin, and CRP, are also found higher in severe COVID-19 [40].

During respiratory virus infection, $\mathrm{XO}$ also acts to induce chemokine secretion (CXC, CXCL1, and CCL2, among others) that are neutrophils chemoattractants [2]. In COVID-19 patients with ARDS, hyperinflammation occurred due to the proinflammation cytokine release in high numbers and also due to the secretion of chemokine in large numbers (CCL2, CCL3, CCL5, CXCL8, CXCL9, and CXCL10, among others) [40]. The release of chemokine in large numbers will enhance the recruitment of neutrophils, increase the number of superoxide anions produced during the phagocytosis process by the neutrophils, which will eventually raise the number of proinflammation cytokines secreted and worsen the inflammation reaction.

Neutrophils' recruitment to the inflammatory sites may become key that explained severity in viral infections, such as influenza, and not limited to SARS-Cov2 [41]. Neutrophils migrations through the closest endothelial near infected cells such as alveolar epithelial cells may cause induced neutrophils apoptotic, neutrophils extravascular trap (NET), and accumulation together with platelets in the endothelial cells [42]. Such a phenomenon may lead to microthrombus formation and may trigger lung hypoxic damage [43-45]. It was mostly a similar mechanism to pneumonia cases in COVID-19 [46]. 


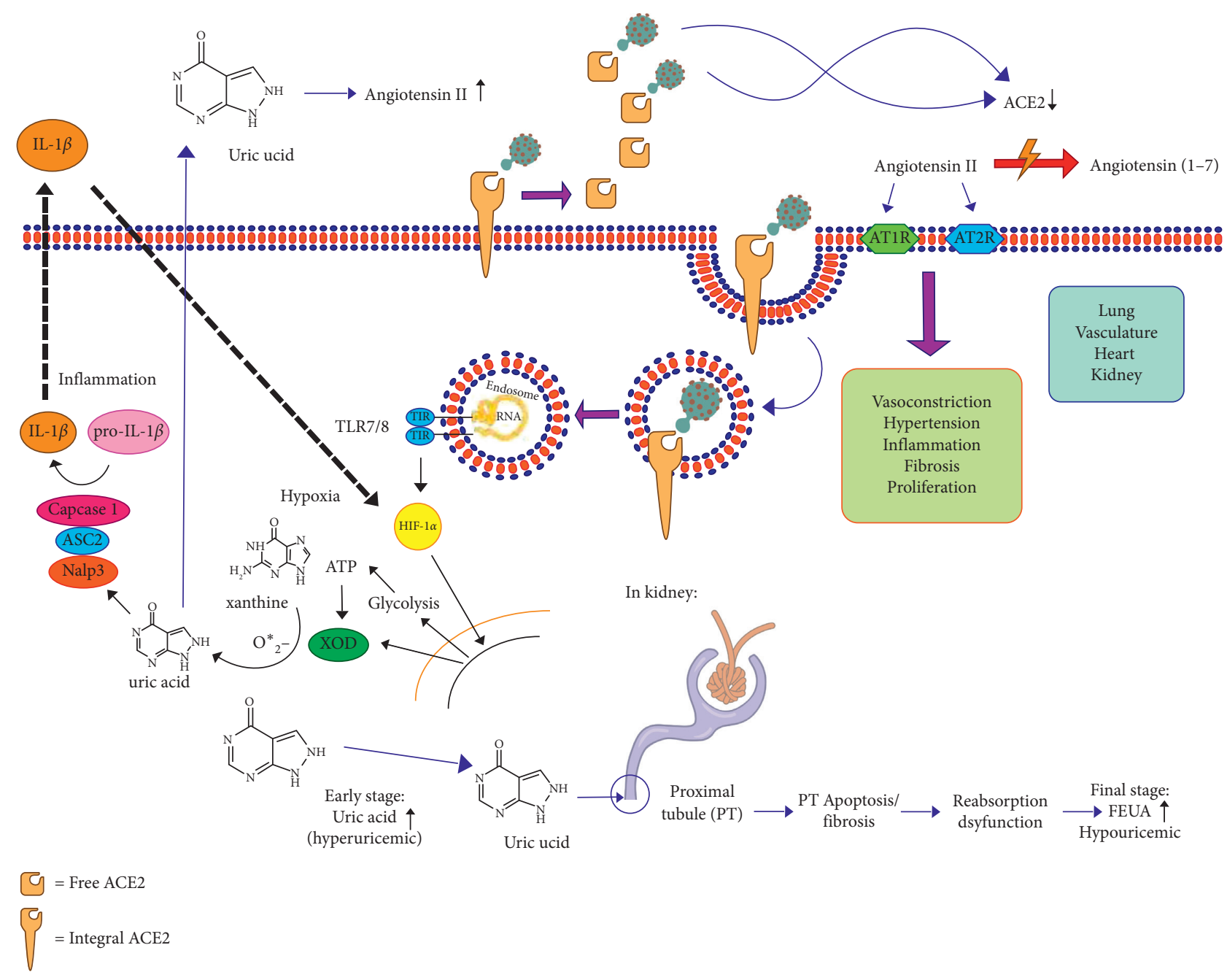

FIgURe 2: Association between XO activity and uric acid level and kidney tubulus proximal.

It is explained in the previous paragraph that during the respiratory virus infection, hyperinflammation especially occurs due to neutrophils recruitment in uninfected cells. The same thing also happens during a gout attack. Neutrophils' recruitment when responding to the presence of monosodium urate crystals is the key factor in acute inflammation or hyperinflammation [47]. However, it is often found that gout attack and inflammation reactions may happen in patients with normal serum uric acid levels. A retrospective study to 30 patients who had gout attacks conducted by Badulescu et al. found that $63.3 \%$ of patients had normal serum uric acid levels [48]. Zhao et al. even said that during a gout attack, $34.92 \%$ of 126 patients had a reduction in serum uric acid level\} [44]. Badulescu et al. also said that the inflammation syndrome was detected in $76.6 \%$ of patients with a high erythrocyte sedimentation rate (ESR) [49]. It can be concluded that patients with normal serum uric acid levels can also have gout attacks and an increase in ESR, which are the marker of the occurrence of inflammation. Soluble uric acid is also known to be able to activate NLRP3 inflammasome [50]. A normal uric acid level or less than $6 \mathrm{mg} / \mathrm{dL}$ can also trigger hyperinflammation. In respiratory virus infection, excessive recruitment of neutrophils seems also influenced by the many cells infected.

The increase in ESR is also commonly found in COVID19 patients, in up to $85 \%$ of total hospitalized patients [51]. It is very likely that this increase in ESR is not followed by the increase in serum uric acid level, as happens in patients having an acute gout attack. Neutrophils to lymphocyte ratio monitoring can also be done and can be used as an indicator of hyperinflammation. Serum uric acid level monitoring may be conducted particularly on COVID-19 patients with ARDS. Lee et al. [52] and Elshafey et al. [38] mentioned that in patients with ARDS, the serum uric acid level is a mortality risk prognosis marker. Serum uric acid in low levels in ARDS patients will usually result in clinical improvements. In contrast, serum uric acid level above the threshold value of $8.4 \mathrm{mg} / \mathrm{dL}$ is known to be associated with the mortality of ARDS patients [38].

Excessive superoxide radical formation can also damage lymphocyte T cells [53] via necrosis [54] that can trigger lymphopenia. Lymphopenia is known to occur in more than $80 \%$ of COVID-19 patients [40], marked by the decrease in circulating $\mathrm{CD}_{4}^{+} \mathrm{T}$ cells and $\mathrm{CD}_{8}^{+} \mathrm{T}$ cells $[55,56]$. The low level of $\mathrm{CD}_{4}^{+}$cells leads to the decrease in 
neutralizing antibodies and gives impact to the disturbance in the immune system balance. The decrease in the cytotoxic $\mathrm{CD}_{8}^{+}$, however, causes weak antibody production and inefficient virus clearance $[54,55]$. Lymphopenic $\mathrm{T}$ cells also have an impact on the reduction of apoptosis ability of phagocytes, which also causes excessive immune response [39].

Excessive immune response, or CSS, caused by cytokine proinflammation, chemokine, and neutrophils production can trigger an acute condition in COVID-19 or ARDS patients. An excessive immune response can also lead to multiorgan failure (MOF), such as lung damage and fibrosis due to endothelial dysfunction. It is already shown that inflammation reaction by $\mathrm{XO}$ or uric acid activity can trigger endothelial dysfunction $[13,21]$.

Endothelial dysfunction by $\mathrm{XO}$ is initiated when $\mathrm{XO}$ in the circulation bind to the sulfated GAG in the surface of endothelial cells $[7,11,57]$, catalyzing the formation of uric acid and superoxide radicals, triggering the production of proinflammation cytokine $[19,21]$, which then independently trigger cell apoptosis [38], disturbing the permeability and the function of cell barrier [58], and finally causing the endothelial dysfunction. Consistent with the above, it is known that XO inhibitor will improve endothelial function, such as in patients with coronary artery disease, chronic heart failure, and DM1 and DM2 [39]. In COVID-19 patients, hypertension and diabetes are comorbid diseases that increase the risk of SARS-CoV-2 infection [40]. In accordance with World Health Organization data, cardiovascular diseases, diabetes, hypertension, chronic respiratory disease, and cancer are comorbid diseases found in fatal cases in COVID-19 patients [39]. In view of the above, the inhibition of $\mathrm{XO}$ activity, including in cases caused by a respiratory virus such as SARS-CoV-2, can be used as the target of therapy, especially to maintain the clinical conditions of COVID-19 patients so that the comorbid diseases do not develop into a serious complication that can lead to MOF and resulting in death.

\section{Xanthine Oxidase (XO) as a Therapeutical Target in Hypoxia in COVID-19}

One study showed that SARS-CoV-2 infections induced formation NET [59]. These extracellular fibers consisted of neutrophils's DNA that binds to pathogenic agents such as viruses and bacteria [60]. However, NETs also beheld undesirable effects to the host, such as induced inflammations, endothelial damage, and microthrombus formation [61]. NETs were also reported to contribute to coagulopathy during HIV infections and play a role during stroke related thrombocyte $[62,63]$. Moreover, a meta-analysis study that assessed histological findings of COVID-19 patients showed that lung damage in patients were caused by alveolar bloodair barrier damage, in parallel with hyaline membrane formation and microthrombus in vein of alveolar vascularate [64]. Therefore, we assumed such incidence that SARSCoV-2 infections induced NET formations.

In COVID-19 patients, ARDS may generally be triggered by alveolar vasoconstriction. Vasoconstriction process may occur due to microthrombus formation in pulmonary capillaries as a response to alveolar hypoxia and an increase in the amount of angiotensin II. As a result, there is inhibition of ACE2 activity by the virus. This causes pulmonary blood flow to flow persistently with high pressure to the alveoli afterward. Furthermore, this may cause an increase in blood vessel pressure in the lung, which later causes vascular fluid leakage into the alveoli and causes edema. Increased edema will cause atelectasis and will trigger pulmonary right-to-left shunting, resulting in an incomplete gas exchange in the alveolus. As a result, oxygen saturation will continue to decrease, and hypoxemia persists even though the administration of the oxygen fraction is increased through oxygen supplementation [45]. This is shown in Figure 3.

Even though ARDS may be induced by alveolar vasoconstriction appears in some patients, recent evidence shows dilatation on pulmonary capillaries [67]. This may be associated with inflammation and endothelial damage due to NET, as described above. Loss of vasoconstriction regulation in response to hypoxia seems to explain the findings of COVID-19 patients without symptoms of shortness of breath (dyspnea). Apart from inflammation in endothelial cells, pulmonary vasoconstriction dysregulation can be associated with an increased amount of VGEF-A, a protein that can mediate vascular dilation, in bronchial alveolar lavage fluid from COVID-19 patients [68]. It is known that viral spike proteins can bind to neuropilin-1, which is a VEGF-A coreceptor and is expressed on pulmonary vascular endothelial cells [69]. This causes VEGF-A to tend to bind to VEGFR-1 and VEGFR-2, which are also expressed on pulmonary vascular endothelial cells and mediate vasodilation.

Even though ARDS triggered by pulmonary hypertension appeared in some patients, a common incidence that may show alveolar vasodilatation [67], which is related to endothelial damage and inflammation due to NETosis as described before. Loss of vasoconstrictions regulations as hypoxia response may be described in asymptomatic COVID-19 patients without dyspnea, commonly dubbed as "happy hypoxia."

In summary, SARS-CoV-2 may trigger NET that causes hypoxic cell damage due to contribution of that radical superoxides that produced by XO. Al-khafaji demonstrated that neutrophils incubated with $\mathrm{XO}$ and hypoxanthine, triggered NET formation. Sequentially, allopurinol administrations to neutrophils show NET formations. Therefore, this may show that allopurinol may be able to reduced NETosis, which may be caused by reduced expression of citrullinated histone H3 (Cit-H3) [66]. Such processes were shown in Figure 4.

Viral infection has been shown to induced XO activity in RSV infections. (2) Uric acid, which is produced by RNA, may play a role in IL-1b formations as shown by Nicholas et al. [70]. Moreover, hypoxia-inducible factor 1 (HIF-1) as hypoxia biomarkers may also contribute to such mechanism [70]. This may also be related to the role of ATP in sequential reactions of IL- $1 \mathrm{~b}$ formation and release, which is a sign of increased catabolic activity by 


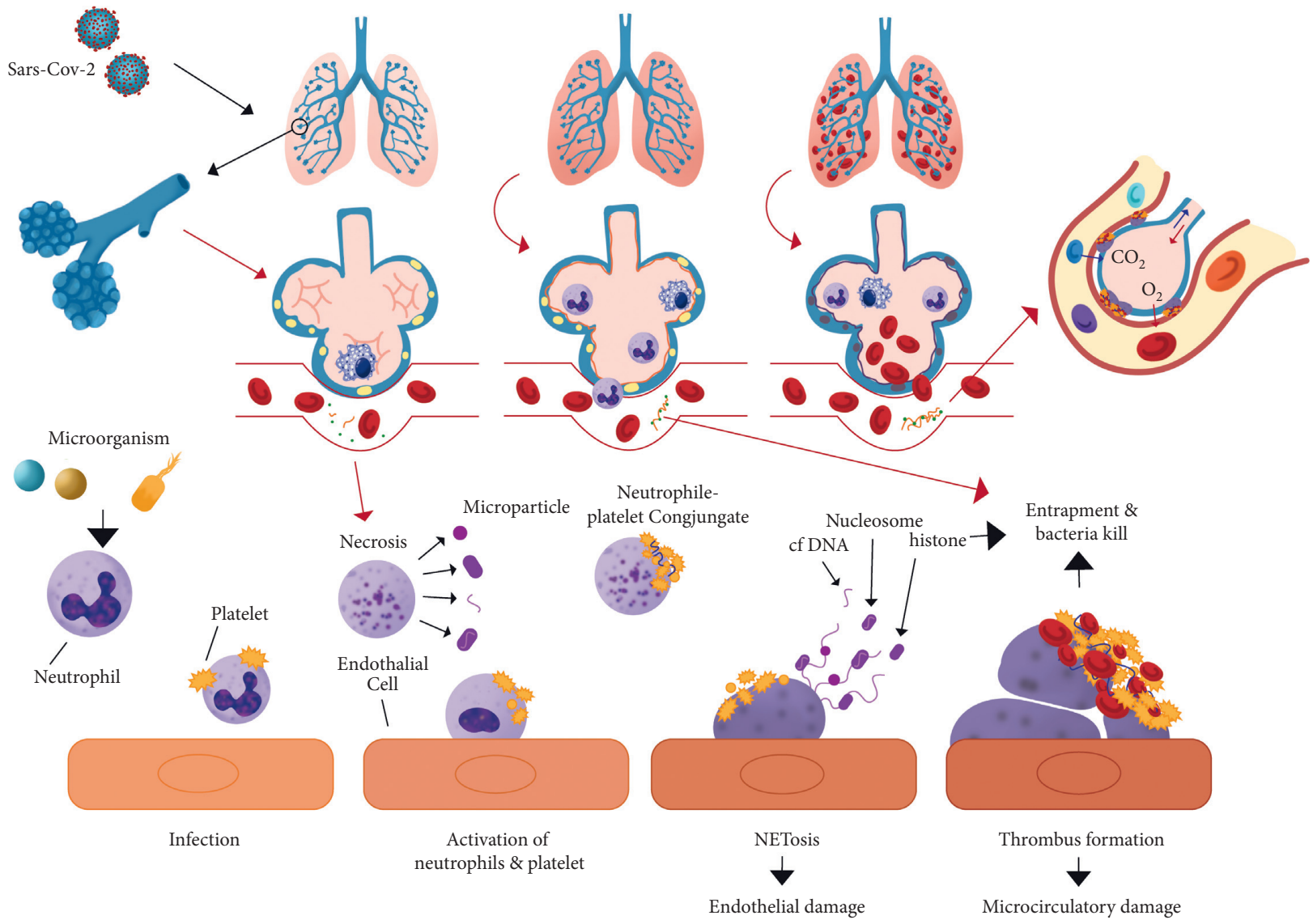

FIGURE 3: mechanism that explained SARS-CoV-2 infections NETosis and relations to hypoxic cell damage. The mechanism was adapted from Zhou et al. and Khafarijiy et al. [65, 66].

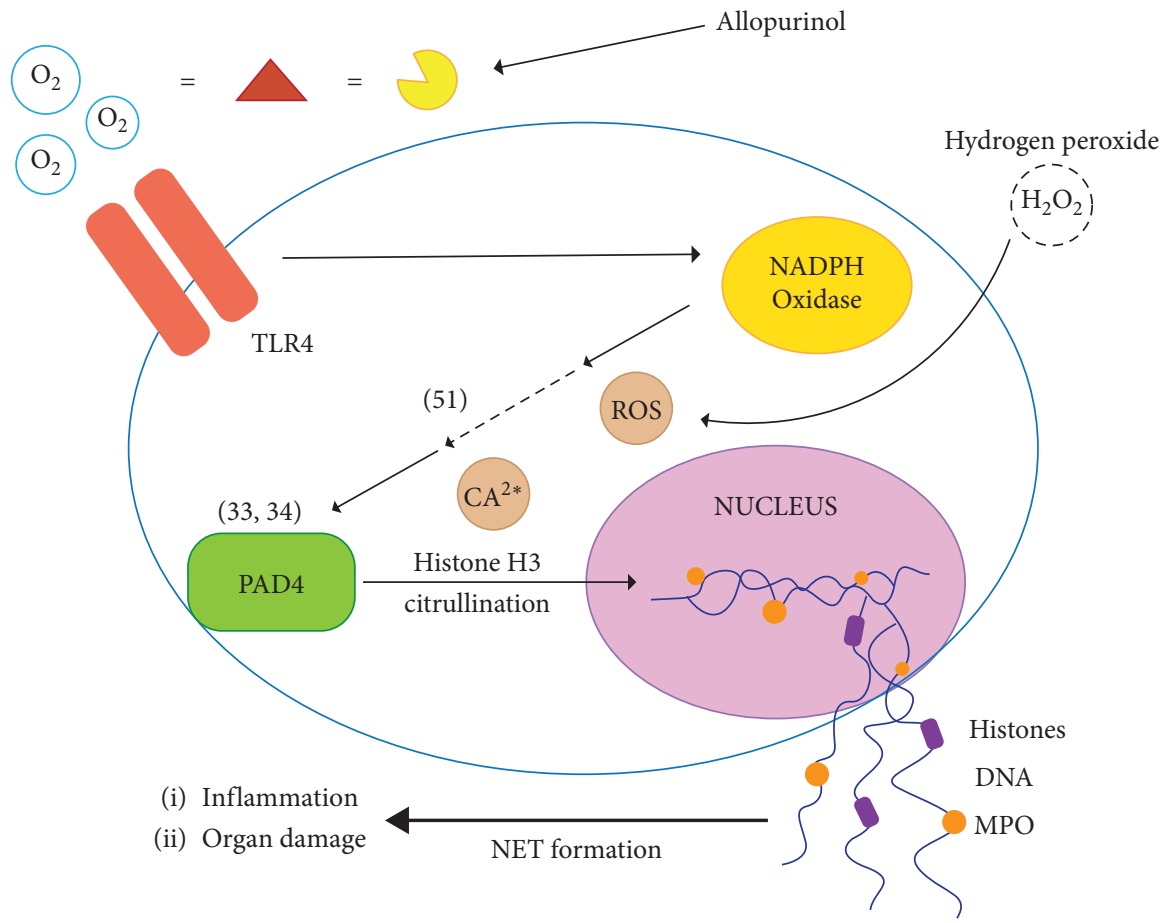

FIgURE 4: Allopurinol suppressed NETosis formations in vitro. XO activity triggered NETosis in vitro while administration of allopurinol inhibits NETosis. The figure was adapted from Khafarijiy et al. [66]. 
the cells. As previously described in Figure 1, CXC, which attracts neutrophils [30], may induce NET formations, hyperinflammations, damage of alveolar capillary endothelial, and microthrombus formations, which later caused hypoxemia as described previously [59, 61, 66]. Therefore, $\mathrm{XO}$ and its catalytic product, uric acid, and superoxide radicals may trigger hypoxic cell damage in COVID-19.

In several studies, uric acid may become a prognosis marker of ARDS, which is caused by the buildup of alveolar fluid [71]. In contrast, in several cases, COVID-19 has conditions of normourisemia or hypouricemia. Werion et al. explained that such conditions may be caused by kidney tubules proximal that have been damaged, which may disrupt uric acid absorption. This may be indicated by an increased level of urine uric acid and fractional excretion uric acid (FEUA) in COVID-19 patients [72]. Koitka et al. also stated that ACE2 were expressed sufficiently in kidney proximal tubulus [73], therefore may be susceptible to SARS-COV-2 infections. Moreover, uric acid has been demonstrated to induce apoptosis in kidney tubules proximal [74]. Both facts may explain hipo/normosermia in COVID-19 patients.

A better perspective of the uric acid drug may be used in COVID-19 therapy as reported by Tardif et al. [75]; at this report, colchicine as a uric acid drug has been reported to reduce $25 \%$ of patients to be hospitalized, $50 \%$ of patients that need a ventilator, and $44 \%$ of deaths [75]. Colchicine has been known to inhibit neutrophils to inflammations sites caused by uric acid crystals. Therefore, allopurinol, which has the same mechanism as colchicine, may potentially behold as having a similar effect to reduced neutrophils recruitment and prevent NETs related to endothelial cells.

Lastly, colchicine and allopurinol are cheap drugs that are more accessible in markets [76], with better-known side effects. Therefore, behold other potential applications to these drugs. However, correct administrations protocols as second lines to that COVID-19 patients should be studied. For allopurinol, a clinical trial should be performed.

\section{Conclusions and Future Prospect}

Control in the formation of proinflammation cytokines causing inflammation is a key factor in disease therapy caused by a respiratory virus infection, including also the disease caused by SARS-CoV-2. In this case, the use of a combination of anti-inflammation and antivirus may be more effective than only using one single modality. The failure in controlling the inflammation reaction during respiratory virus infection can lead to endothelial dysfunction resulting in MOF and CSS leading to ARDS. It is also already shown that XO activity has an important role in inflammation reaction during respiratory virus infection. Therefore, $\mathrm{XO}$ can be used as the target of anti-inflammation therapy caused by respiratory viruses, including also COVID-19.

$\mathrm{XO}$ and its catalytic product are potential therapeutic targets in COVID-19 patients, in particular during the early phase of infections or while symptoms appear. Uric acid may also be potential for monitoring inflammation and hypoxia in COVID-19 patients during the early step of infections in patients with uric acid comorbidity or others influenced by uric acid conditions.

\section{Conflicts of Interest}

The authors declare that they have no conflicts of interest.

\section{Acknowledgments}

This review was supported by Publikasi Terindeks Internasional (PUTI) Penugasan (Covid-19) Universitas Indonesia 2020 (Grant ID: NKB-2615/UN2.RST/HKP.05.00/ 2020).

\section{References}

[1] S. L. Kale, K. Agrawal, S. N. Gaur, and N. Arora, "Cockroach protease allergen induces allergic airway inflammation via epithelial cell activation," Scientific Reports, vol. 7, Article ID 42341, 2017.

[2] W. Fonseca, C. Malinczak, C. Schuler et al., "Uric acid pathway activation during respiratory virus infection promotes Th2 immune response via innate cytokine production and ILC2 accumulation," Mucosal Immunology, vol. 13, 2020.

[3] F. Martinon, V. Pétrilli, A. Mayor et al., "Tschopp JGoutassociated uric acid crystals activate the NALP3 inflammasome," Nature, vol. 440, pp. 237-241, 2006.

[4] C.-J. Chen, Y. Shi, A. Hearn et al., "MyD88-Dependent IL-1 receptor signaling is essential for gouty inflammation stimulated by monosodium urate crystals," Journal of Clinical Investigation, vol. 116, no. 8, pp. 2262-2271, 2006.

[5] C. Enroth, B. T. Eger, K. Okamoto, T. Nishino, T. Nishino, and E. F. Pai, "Crystal structures of bovine milk xanthine dehydrogenase and xanthine oxidase: structure-based mechanism of conversion," Proceedings of the National Academy of Sciences, vol. 97, no. 20, Article ID 10723, 2000.

[6] N. Cantu-Medellin and E. E. Kelley, "Xanthine oxidoreductase-catalyzed reactive species generation: a process in critical need of reevaluation," Redox Biology, vol. 1, no. 1, pp. 353-358, 2013.

[7] E. E. Kelley, T. Hock, N. K. H. Khoo et al., "Moderate hypoxia induces xanthine oxidoreductase activity in arterial endothelial cells," Free Radical Biology and Medicine, vol. 40, no. 6, pp. 952-959, 2006.

[8] Y. Kuwabara, T. Nishino, K. Okamoto et al., "Unique amino acids cluster for switching from the dehydrogenase to oxidase form of xanthine oxidoreductase," Proceedings of the National Academy of Sciences of the United States of America, vol. 100, no. 14, pp. 8170-8175, 2003.

[9] C. M. Harris and V. Massey, "The oxidative half-reaction of xanthine dehydrogenase with NAD; reaction kinetics and steady-state mechanism," Journal of Biological Chemistry, vol. 272, no. 45, pp. 28335-28341, 1997.

[10] D. N. Granger, G. Rutili, and J. M. McCord, "Superoxide radicals in feline intestinal ischemia," Gastroenterology, vol. 81, no. 1, pp. 22-29, 1981.

[11] M. Houston, A. Estevez, P. Chumley et al., "Binding of xanthine oxidase to vascular endothelium: kinetic characterization and oxidative impairment of nitric oxide- 
dependent signaling," Journal of Biological Chemistry, vol. 274, no. 8, pp. 4985-4994, 1999.

[12] P. Bianciardi, R. Scorza, G. Ghilardi, and M. Samaja, "Xanthine oxido-reductase activity in ischemic human and rat intestine," Free Radical Research, vol. 38, pp. 919-925, 2004.

[13] A. Sturza, O. Duicu, A. Vaduva et al., "Hydrogen peroxide promotes endothelial dysfunction by decreasing nitric oxide bioavailability in experimental diabetes mellitus," Revista de Chimie, vol. 67, pp. 2302-2305, 2016.

[14] M.-C. Desco, M. Asensi, R. Márquez et al., "Xanthine oxidase is involved in free radical production in type 1 diabetes: protection by allopurinol," Diabetes, vol. 51, no. 4, pp. 1118-1124, 2002.

[15] C. A. J. Farquharson, R. Butler, A. Hill, J. J. F. Belch, and A. D. Struthers, "Allopurinol improves endothelial dysfunction in chronic heart failure," Circulation, vol. 106, no. 2, pp. 221-226, 2002.

[16] O. A. Khomich, S. N. Kochetkov, B. Bartosch, and A. V. Ivanov, "Redox biology of respiratory viral infections," Viruses, vol. 10, no. 8, 2018.

[17] T. Eleftheriadis, G. Pissas, A. Karioti et al., "Uric acid induces caspase- 1 activation, IL- $1 \beta$ secretion and $\mathrm{P} 2 \mathrm{X} 7$ receptor dependent proliferation in primary human lymphocytes," Hippokratia, vol. 17, no. 2, pp. 141-145, 2013.

[18] T. Gicquel, S. Robert, P. Loyer et al., "IL-1 $\beta$ production is dependent on the activation of purinergic receptors and NLRP3 pathway in human macrophages," The FASEB Journal, vol. 29, no. 10, pp. 4162-4173, 2015.

[19] W. Yin, Q.-L. Zhou, S.-X. OuYang, Y. Chen, Y.-T. Gong, and Y.-M. Liang, "Uric acid regulates NLRP3/IL-1 $\beta$ signaling pathway and further induces vascular endothelial cells injury in early CKD through ROS activation and $\mathrm{K}(+)$ efflux," BMC Nephrology, vol. 20, no. 1, p. 319, 2019.

[20] S. Neumann, N. J. Shields, T. Balle, M. Chebib, and A. N. Clarkson, "Innate immunity and inflammation poststroke: an $\alpha 7$-nicotinic agonist perspective," International Journal of Molecular Sciences, vol. 16, no. 12, pp. 29029-29046, 2015.

[21] W. Cai, X.-M. Duan, Y. Liu et al., "Uric acid induces endothelial dysfunction by activating the HMGB1/RAGE signaling pathway," BioMed Research International, vol. 2017, Article ID 4391920, , 2017.

[22] J. Xiao, X. Zhang, R. Han, C. Fu, W. Chen, and Z. Ye, "Uric acid induces TLR4-dependent innate immune response but not HLA-DR and CD40 activation in renal proximal tubular epithelial cells," International Journal of Clinical and Experimental Pathology, vol. 9, pp. 940-949, 2016.

[23] K. Yasui, N. Kobayashi, T. Yamazaki et al., "Superoxide dismutase (SOD) as a potential inhibitory mediator of inflammation via neutrophil apoptosis," Free Radical Research, vol. 39, pp. 755-762, 2005.

[24] L. S. da Costa, A. Outlioua, A. Anginot, K. Akarid, and D. Arnoult, "RNA viruses promote activation of the NLRP3 inflammasome through cytopathogenic effect-induced potassium efflux," Cell Death \& Disease, vol. 10, no. 5, p. 346, 2019.

[25] S. McClellan, X. Jiang, R. Barrett, and L. D. Hazlett, "Highmobility group box 1: a novel target for treatment of Pseudomonas aeruginosa keratitis," Journal of Immunology, vol. 194, no. 4, pp. 1776-1787, 2015.

[26] P. A. F. Pacheco and R. X. Faria, "The potential involvement of P2X7 receptor in COVID-19 pathogenesis: a new therapeutic target?" Scandinavian Journal of Immunology, vol. 93, no. 2, Article ID e12960, 2021.
[27] C. Huang, Y. Wang, X. Li et al., "Clinical features of patients infected with 2019 novel coronavirus in Wuhan, China," Lancet, vol. 395, no. 10223, pp. 497-506, 2020.

[28] N. Riteau, P. Gasse, L. Fauconnier et al., "Extracellular ATP is a danger signal activating $\mathrm{P} 2 \mathrm{X} 7$ receptor in lung inflammation and fibrosis," American Journal of Respiratory and Critical Care Medicine, vol. 182, no. 6, pp. 774-783, 2010.

[29] A. S. Ojo, S. A. Balogun, O. T. Williams, and O. S. Ojo, "Pulmonary fibrosis in COVID-19 survivors: predictive factors and risk reduction strategies," Pulmonary Medicine, vol. 2020, Article ID 6175964, , 2020.

[30] T. A. Miura and K. V. Holmes, "Host-pathogen interactions during coronavirus infection of primary alveolar epithelial cells," Journal of Leukocyte Biology, vol. 86, no. 5, pp. 1145-1151, 2009.

[31] Q. Zhang and X. Huang, "Induction of interleukin-6 by coal containing bioavailable iron is through both hydroxyl radical and ferryl species," Journal of Biosciences, vol. 28, pp. 95-100, 2003.

[32] D. Swaroopa, K. Bhaskar, T. Mahathi et al., "Association of serum interleukin-6, interleukin-8, and acute physiology and chronic Health evaluation II score with clinical outcome in patients with acute respiratory distress syndrome," Indian Journal of Critical Care Medicine, vol. 20, no. 9, pp. 518-525, 2016.

[33] L. Kilpatrick and M. Harris, "Cytokines and inflammatory response in the fetus and neonate," Fetal and Neonatal Physiology, vol. 2, pp. 1555-1572, 2003.

[34] R. C. Andreas, R. Markus, L. Max et al., "Ccl2 and $\mathrm{Ccl} 3$ mediate neutrophil recruitment via induction of protein synthesis and generation of lipid mediators," Arteriosclerosis, Thrombosis, and Vascular Biology, vol. 29, no. 11, pp. 17871793, 2009.

[35] A. Papi, M. Contoli, P. Gasparini et al., "Role of xanthine oxidase activation and reduced glutathione depletion in rhinovirus induction of inflammation in respiratory epithelial cells," Journal of Biological Chemistry, vol. 283, no. 42, pp. 28595-28606, 2008.

[36] B. Chen, C. Lu, H.-Q. Gu et al., "Serum uric acid concentrations and risk of adverse outcomes in patients with COVID-19," Frontiers in Endocrinology, vol. 12, Article ID 633767, 2021.

[37] V.-C. Wu, J.-W. Huang, P.-R. Hsueh et al., "SARS research group of national taiwan university college of medicine and national taiwan university hospital: renal hypouricemia is an ominous sign in patients with severe acute respiratory syndrome," American Journal of Kidney Diseases, vol. 45, no. 1, pp. 88-95, 2005.

[38] M. Elshafey, A. M. A. Mossalam, M. Y. Makharita, and A. Elewa, "Prognostic role of serum uric acid in acute respiratory distress syndrome patients: a preliminary study," Egyptian Journal of Chest Diseases and Tuberculosis, vol. 64, no. 1, pp. 197-202, 2015.

[39] P. P. Liu, A. Blet, D. Smyth, and H. Li, "The science underlying COVID-19: implications for the cardiovascular system," Circulation, vol. 142, no. 1, pp. 68-78, 2020.

[40] A. Susilo, C. Rumende, C. Pitoyo et al., "Coronavirus disease 2019: tinjauan literatur terkini," Jurnal Penyakit Dalam Indonesia, vol. 7, p. 45, 2020.

[41] R. Alon, M. Sportiello, S. Kozlovski et al., "Leukocyte trafficking to the lungs and beyond: lessons from influenza for COVID-19," Nature Reviews Immunology, vol. 21, no. 1, pp. 49-64, 2021. 
[42] J. Liu, Z. Pang, G. Wang et al., "Advanced role of neutrophils in common respiratory diseases," Journal of Immunology Research, vol. 2017, Article ID 6710278, , 2017.

[43] R. L. Conhaim, M. J. Mangino, W. F. Dovi, K. E. Watson, T. F. Warner, and B. A. Harms, "microthrombus formation may trigger lung injury after acute blood loss," Shock, vol. 34, no. 6, pp. 601-607, 2010.

[44] E. A. Middleton, X.-Y. He, F. Denorme et al., "Neutrophil extracellular traps contribute to immunothrombosis in COVID-19 acute respiratory distress syndrome," Blood, vol. 136, no. 10, pp. 1169-1179, 2020.

[45] S. Dhont, E. Derom, E. Van Braeckel, P. Depuydt, and B. N. Lambrecht, "The pathophysiology of 'happy' hypoxemia in COVID-19," Respiratory Research, vol. 21, no. 1, p. 198, 2020.

[46] L. C. Price, C. McCabe, B. Garfield, and S. J. Wort, "Thrombosis and COVID-19 pneumonia: the clot thickens!" European Respiratory Journal, vol. 56, no. 1, Article ID 2001608, 2020.

[47] A. So, "How to regulate neutrophils in gout," Arthritis Research \& Therapy, vol. 15, no. 5, p. 118, 2013.

[48] M. Bădulescu, L. Macovei, and E. Rezuş, "Acute gout attack with normal serum uric acid levels," Revista medico-chirurgicala a Societatii de Medici si Naturalisti din Iasi, vol. 118, no. 4, pp. 942-945, 2014.

[49] T. Zhao, X. Lv, L. Cao et al., "Renal excretion is a cause of decreased serum uric acid during acute gout," International Journal of Rheumatic Diseases, vol. 21, pp. 1723-1727, 2018.

[50] T. T. Braga, M. F. Forni, M. Correa-Costa et al., "Soluble uric acid activates the NLRP3 inflammasome," Scientific Reports, vol. 7, Article ID 39884, 2017.

[51] G. Lippi and M. Plebani, "Laboratory abnormalities in patients with COVID-19 infection," Clinical Chemistry and Laboratory Medicine, vol. 58, no. 7, pp. 1131-1134, 2020.

[52] H. W. Lee, S. M. Choi, J. Lee et al., "Serum uric acid level as a prognostic marker in patients with acute respiratory distress syndrome," Journal of Intensive Care Medicine, vol. 34, no. 5, pp. 404-410, 2019.

[53] M. G. Battelli, A. Abbondanza, P. L. Tazzari, A. Bolognesi, R. M. Lemoli, and F. T. Stirpe, "Lymphocyte killing by a xanthine-oxidase-containing immunotoxin," Cancer Immunology, Immunotherapy, vol. 35, no. 6, pp. 421-425, 1992.

[54] M. G. Battelli, S. Musiani, P. L. Tazzari, and F. Stirpe, "Oxidative stress to human lymphocytes by xanthine oxidoreductase activity," Free Radical Research, vol. 35, no. 6, pp. 665-679, 2001.

[55] Z. He, C. Zhao, Q. Dong et al., "Effects of severe acute respiratory syndrome (SARS) coronavirus infection on peripheral blood lymphocytes and their subsets," International Journal of Infectious Diseases, vol. 9, no. 6, pp. 323-330, 2005.

[56] G. Chen, D. Wu, W. Guo et al., "Clinical and immunological features of severe and moderate coronavirus disease 2019," Journal of Clinical Investigation, vol. 130, no. 5, pp. 26202629, 2020.

[57] M. A. Incalza, R. D’Oria, A. Natalicchio, S. Perrini, L. Laviola, and F. Giorgino, "Oxidative stress and reactive oxygen species in endothelial dysfunction associated with cardiovascular and metabolic diseases," Vascular Pharmacology, vol. 100, pp. 119, 2018.

[58] C. T. Capaldo and A. Nusrat, "Cytokine regulation of tight junctions," Apical Junctional Complexes Part II, vol. 1788, no. 4, pp. 864-871, 2009.

[59] A. Arcanjo, J. Logullo, C. C. B. Menezes et al., "The emerging role of neutrophil extracellular traps in severe acute respiratory syndrome coronavirus 2 (COVID-19)," Scientific Reports, vol. 10, no. 1, Article ID 19630, 2020.

[60] V. Brinkmann, U. Reichard, C. Goosmann et al., "Neutrophil extracellular traps kill bacteria," Science, vol. 303, no. 5663, p. 1532, 2004.

[61] T. Iba, N. Hashiguchi, I. Nagaoka, Y. Tabe, and M. Murai, "Neutrophil cell death in response to infection and its relation to coagulation," Journal of Intensive Care, vol. 1, no. 1, p. 13, 2013.

[62] R. Sivanandham, E. Brocca-Cofano, N. Krampe et al., "Neutrophil extracellular trap production contributes to pathogenesis in SIV-infected nonhuman primates," Journal of Clinical Investigation, vol. 128, no. 11, pp. 5178-5183, 2018.

[63] J. Vallés, A. Lago, M. T. Santos et al., "Neutrophil extracellular traps are increased in patients with acute ischemic stroke: prognostic significance," Thrombosis and Haemostasis, vol. 117, no. 10, pp. 1919-1929, 2017.

[64] A. Maiese, A. C. Manetti, R. La Russa et al., "Autopsy findings in COVID-19-related deaths: a literature review," Forensic Science, Medicine, and Pathology, 2020.

[65] X. Zhou, Y. Li, and Q. Yang, “Antiplatelet therapy after percutaneous coronary intervention in patients with COVID19," Circulation, vol. 141, no. 22, pp. 1736-1738, 2020.

[66] A. B. Al-Khafaji, S. Tohme, H. O. Yazdani, D. Miller, H. Huang, and A. Tsung, "Superoxide induces neutrophil extracellular trap formation in a TLR-4 and NOX-dependent mechanism," Molecular Medicine, vol. 22, no. 1, pp. 621-631, 2016.

[67] M. Lang, A. Som, D. Carey et al., "Pulmonary vascular manifestations of COVID-19, pneumonia," Radiology: Cardiothoracic Imaging, vol. 2, no. 3, Article ID e200277, 2020.

[68] A. Moutal, L. F. Martin, L. Boinon et al., "SARS-CoV-2 spike protein Co-opts VEGF-A/Neuropilin-1 receptor signaling to induce analgesia," Pain, vol. 162, no. 1, pp. 243-252, 2021.

[69] J. L. Daly, B. Simonetti, K. Klein et al., "Neuropilin-1 is a host factor for SARS-CoV-2 infection," Science, vol. 370, no. 6518, p. $861,2020$.

[70] S. A. Nicholas, V. V. Bubnov, I. M. Yasinska, and V. V. Sumbayev, "Involvement of xanthine oxidase and hypoxia-inducible factor 1 in toll-like receptor 7/8-mediated activation of caspase 1 and interleukin-1 $\beta$," Cellular and Molecular Life Sciences, vol. 68, no. 1, pp. 151-158, 2011.

[71] I. Pratomo, A. Ariane, A. Tedjo, R. Heryanto, and R. I. Paramita, "Xanthine oxidase inhibition in SARS-CoV-2 infection: the mechanism and potency of allopurinol and febuxostat in COVID-19 management," Medical Journal of Indonesia, vol. 30, pp. 75-80, 2020.

[72] A. Werion, L. Belkhir, M. Perrot et al., "SARS-CoV-2 causes a specific dysfunction of the kidney proximal tubule," Kidney International, vol. S0085-2538, no. 20, pp. 30912-30921, 2020.

[73] A. Koitka, M. E. Cooper, M. C. Thomas, and C. Tikellis, "Angiotensin converting enzyme 2 in the kidney," Clinical and Experimental Pharmacology and Physiology, vol. 35, no. 4, pp. 420-425, 2008.

[74] Z. Li, Y. Sheng, C. Liu et al., "Nox4 has a crucial role in uric acid-induced oxidative stress and apoptosis in renal tubular cells," Molecular Medicine Reports, vol. 13, no. 5, pp. 4343-4348, 2016.

[75] J.-C. Tardif, N. Bouabdallaoui, P. L. L'Allier et al., "Efficacy of colchicine in non-hospitalized patients with COVID-19," medRxiv, 2021.

[76] M. Meltzer, L. T. Pizzi, and E. Jutkowitz, "Payer decisionmaking with limited comparative and cost effectiveness data: the case of new pharmacological treatments for gout," Evidence Based Medicine, vol. 17, no. 4, p. 105, 2012. 